\title{
Oil Prices, Exchange Rate and Prices for Agricultural Commodities: Empirical Evidence from Russia
}

\author{
D. Burakov
}

Department of Monetary Relations \& Monetary Policy, Financial University under the Government of Russian Federation

\begin{abstract}
In this paper, we investigate long and short-term impact of changes in oil prices and the exchange rate on prices of seven groups of agricultural products in Russia (buckwheat, grain crops, potatoes, oat, wheat, rye, barley). In this paper, Granger causality approach is applied to test long-run interlinkages with monthly data from January 1999 to October 2015. For testing the response of agricultural prices to sudden shocks in oil prices and exchange rate in the short run, we use impulse-response techniques. The results of impulse response analysis show that agricultural prices are not particularly sensitive to changes in oil prices and the exchange rate of Russian ruble in the short term, except for imported commodities. In the long run, Granger causal relationship between agricultural prices and oil prices is missing, and with exchange rate is observed only in case of imported agricultural goods.
\end{abstract}

\section{Keywords}

Agricultural commodity, world oil prices, exchange rate, Granger causality test, impulse response analysis.

Burakov, D. (2016) "Oil Prices, Exchange Rate and Prices for Agricultural Commodities: Empirical Evidence from Russia", AGRIS on-line Papers in Economics and Informatics, Vol. 8, No. 2, pp. 33-47. ISSN 1804-1930. DOI: 10.7160/aol.2016.080203.

\section{Introduction}

\section{Russian agricultural market: current state}

Due to technological development, and slow population growth in the world, the prediction of Paul Samuelson about large-scale food crisis did not come true. During the 1990 s and the first half of the 2000s a large proportion of agricultural prices remained relatively stable. However, due to natural disasters, catastrophes and other technological and environmental factors, agricultural prices have increased substantially. The prices for such agricultural commodities as grain crops and wheat has doubled in the past few years. According to data provided by the IMF, the IMF's index of internationally traded agricultural products increased by $130 \%$ from January 2002 to June 2008 and 56\% from January 2007 to June 2008 (Keith, 2008).

Russia is a major producer and consumer of a wide range of agricultural products. As one of the important players in the global markets of energy and agricultural products, Russia is very sensitive to changes in the prices of agricultural products, not to mention the oil prices. The sharp rise in prices of some crops, not to mention the general trend of rising prices in the agroindustry in the world markets, was due to a lack of supply and high production costs. (Figure 1).

For example, the price of buckwheat reached in June 2008 long-term peak and amounted to nearly 7,600 rubles per tonne. Compared with the previous year, the growth amounted to almost $30 \%$. In the period from 2010 to 2012 , the average price of buckwheat in Russia amounted to 25000 . A similar trend of rising prices of agricultural products is inherent to other cultures. Although the peak of growth of prices for buckwheat and wheat beginning in 2010 s passed, the price growth is gradually recovering and gaining momentum. Frequent oscillations in agricultural prices have an impact on many other groups of the consumer goods. So, for example, price of pork in Russia during the boom years rose by $45 \%$ in 2008 and $82 \%$ in the period of 2010-2012. Rising grain prices pushed up the cost of pork production in terms of costs for fattening (Federal Service of State Statistics of Russia).

So, the rise in prices on world agricultural markets leads to disruption of the economic balance, balance in many countries, with particular impact on developing countries. On the one hand, high food 


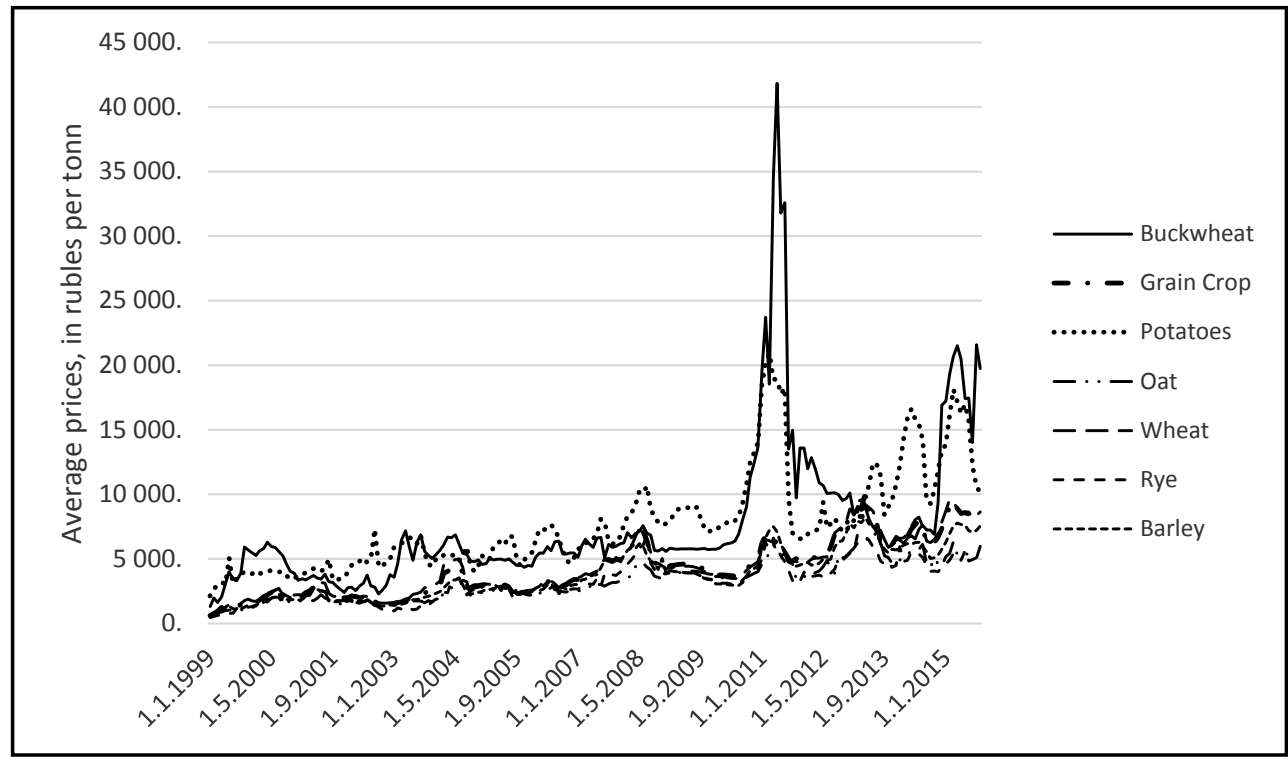

Source: Federal Service of State Statistics of Russia.

Figure 1. Price dynamics of main agricultural commodities in Russia (RR/ton)

prices improve economic condition of exporting countries, positively affecting the balance of payments, as in the case of the USA, Canada and partly Russia. On the other hand, the number of countries - net importers of agricultural products is three times more than the number of countries net exporters (von Braun, 2008). As a consequence, importers, suffered significant losses during crises. The amount of expenses and crisis payments from the authorities has been substantially increased to cover cyclical effects.

Thus, the rise in world food prices is not only good for the exporting countries, but also is a curse. A rise in global prices is pushing manufacturers to increase prices in domestic markets, thereby putting pressure on the household sector. Thus, according to the Food and Agriculture Organization (FAO), developing countries dependent on agricultural imports, are forced to pay additional costs in the amount of 324 billion US dollars in connection with growth of world prices for food (FAOSTAT, 2015). In terms of sustainable growth trend of food prices, authorities of many countries are asking themselves a question about the factors influencing formation of tendency to their growth.

For example, Abbott, et al. (2008) put forward an idea that there were three main variables, which are also recognized by most economists, namely the abundance of demand, the U.S. dollar and the dependence of agriculture from energy industry. Among these three determinants, it is believed that the increased energy prices play a decisive role and affect food prices through direct and indirect channels. World oil prices skyrocketed to 140 us dollars per barrel by the end of the 2000 s with about 20 dollars per barrel in the late 1990s (Figure 2).

Hanson et al (1993) conducted a study on the linkages between energy and agricultural prices in importing countries, using model of input-output, and found that an increase in oil prices increases the cost of crops. The increase in oil prices leads to an increase in costs in the fixed capital, and also creates an additional shed in transportation costs. On the other hand, the sharp rise in oil prices stimulates ethanol production - the main substitute of oil. Then the expansion of demand for biofuels causes higher agricultural prices. Many countries start stimulating and supporting programs for production of ethanol, which indirectly increases demand for agricultural products. For example, according to the Renewable Fuels Association, USA, as the largest producer of ethanol, has allocated around $25 \%$ of crops for its production, thereby increasing the growth of prices for the crop. Moreover, Harri et al. (2009) found that because most oil transactions is held in U.S. dollars, and the price of agricultural commodities on domestic markets is established in national currency, another indirect channel for growth in the price of food is the exchange rate of the national currency (Figure 3).

Impairment or strengthening of the national currency affects the export price and the price of the purchase from the exporting countries. 


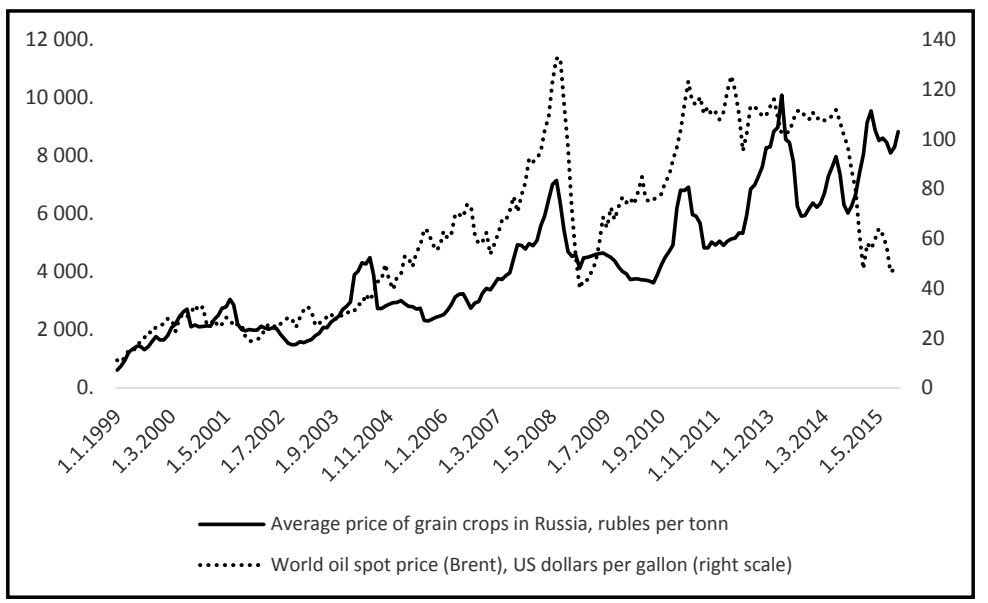

Source: Federal Service of State Statistics of Russia.

Figure 2: Prices of international crude oil (US dollar/barrel) and wheat (Russian rubles/ton)

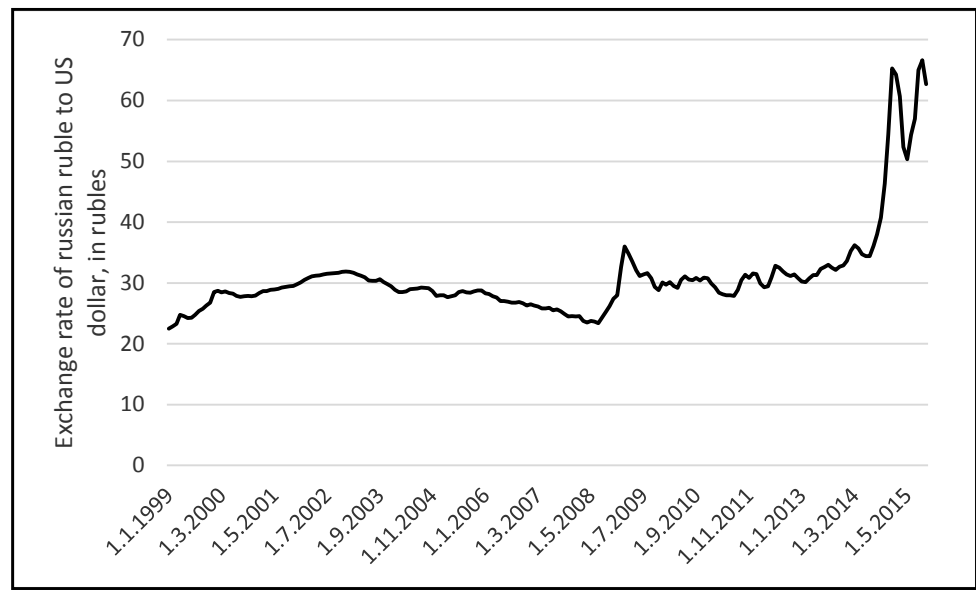

Source: Bank of Russia

Figure 3: Exchange rate of Russian ruble to US dollar.

For example, the devaluation of the Russian ruble will make agricultural products cheaper in comparison with other countries-exporters in the short term. As equilibrium restores, new equilibrium price level will be set at a higher level on the national market. Conversely, the strengthening of the Russian ruble will make the agricultural products more expensive, than in other countries, thereby reducing demand for products from Russia. The reduction of domestic demand in turn will bring the prices to a new equilibrium level.

Thus, it can be assumed that the existing knowledge about direct and indirect channels of influence of oil prices on agricultural prices in developing countries is uncertain and depends on many factors. In this article, we will discuss direct and indirect channels of transmission from oil prices to agricultural prices in the short and long term. When choosing agricultural variables for analysis we agree with the view of Baffes (2007), according to which prices of individual agricultural goods is preferable to using an average of prices for all agricultural products. We apply Granger causality test and impulse response analysis to test long run and short run effects respectively. Understanding of the relationships between oil prices and domestic agricultural prices will allow the national authorities of countries, both exporters and importers of agricultural products to establish optimal monetary and sectoral policies to support agro sector. A sufficient level of production and supply of food is the key and guarantee of food security. Major manufacturers and farmers will then be able to adjust their operating policies and expectations, thereby reducing exposure to risks from changes in the volume of demand and fluctuations in the exchange rate. 
Given the above, the aim of this study is to determine elasticity of prices for a group of agricultural commodities in Russia to shocks in oil prices and exchange rate of the national currency in the short and long run.

\section{Literature review}

The apparent coincidence of the parallel growth of oil prices and agricultural prices has attracted attention of many researchers worldwide. As a rule, most of their attention was paid to either the study of the relationship between agricultural prices and biofuel, or fluctuations in the exchange rate.

In some outstanding works, indicate the relationship between crude oil prices and agricultural prices. Esmaeili and Shokoohi (2011) found that oil prices have an indirect effect on agricultural prices. Campiche et al. (2007) investigated the co-variability between crude oil prices and a number of agricultural crops during the period from 2003 to 2007. Diagnostics through Johansen cointegration test allowed making a conclusion about the absence of cointegration for the period from 2003 to 2005. However, the prices of grain and soybeans were in cointegration with oil prices in the period from 2006 to 2007. Shocks in oil prices can explain only a small proportion of changes in agricultural prices to food crisis in 2006-2007, while in the post-crisis period, the role of oil prices as the explanatory variable increases (Wang et al., 2014). Nazlioglu (2011) found the existence of a stable causal relationship between oil and grain prices. In a similar study, Yu et al. (2006) analyzed the relationship between oil prices and vegetable products. The results of the Johansen cointegration test showed that the impact of oil prices on prices of agricultural goods is statistically insignificant for the studied period.

In the study, Baffes (2007) argues that there is a relationship between oil prices and 35 international agricultural traded goods for the period from 1960 to 2005 . After determining the regression equation, the author claims that if oil prices remain high for some time, an agricultural boom is likely to last longer than in the absence of growth in oil prices. In addition, Baffes suggested to use individual prices for agricultural products in order to optimize the quality of regression models. Xiaodong Du et al. (2010) found that shocks in oil prices lead to a spike in agricultural prices due to increased linkages between the agricultural and energy sectors. The authors of this study used weekly prices of futures for oil, grain and wheat from 1998 to 2009 and applied a Bayesian Markov Monte
Carlo method.

The last two studies speak in favor of the existence of significant correlation between agricultural and oil prices. However, a number of researchers come to alternate conclusions. For example, Zhang and Reed (2008) found that changes of agricultural prices in China are not the result of changes in world oil prices.

In addition, it should be noted that there are alternative linkages between oil prices and agricultural prices. So, Abbot et. al (2008) suggested that an increase in the current account leads to a depreciation of the US dollar, making exports more attractive than imports (exchange rate channel).

Currently, given the scale of international trade, the exchange rate is perhaps a key factor in determining the macroeconomic situation, not to mention attractiveness of the national economy. However, decades ago, the role of exchange rate in domestic markets for obvious reasons was underestimated. And it was not until 1974, when the brilliant work of Schuh (1974) on the role of exchange rate in agricultural trade has appeared. In this study, the author assumed that the overvalued dollar has reduced exports, due to the appearance of additional costs in importing countries. Kost (1976) conducted a study of theoretical bases used to assess the impact of exchange rate changes on commodities' trade volumes in the national economy. At the end, he came to conclusion that there are limits to how price and volume can change in response to changes in the exchange rate. At the same time, Vellianitis-Fidas (1976) conducted a cross-sectional study using stepwise ordinary least squares (OLS) method using data of different time periods. Kost (1976) and VellianitisFidas (1976) in the end came to conclusion that the depreciation of the US dollar was not the cause of high prices in 1972-1973. Chambers (1981) used regression analysis in order to test Granger causality between money supply and agricultural exports and lending rates. The results of the study were in line with other authors, and showed that the money supply (the value of the U.S. dollar) plays a role in the volume of agricultural trade.

On contrary, Batten and Belongia (1984) defended the view that the exchange rate is insignificant and plays no special role. In their opinion, the cornerstone of demand for exports is the changing income of households in the importing countries. Chambers (1984) developed a theoretical model to assess short-term effects of changes in monetary policy on the agricultural sector. $\mathrm{He}$ 
also developed a VAR model for the resolution of statistical problems with the calculations. Koo (2009) investigated reasons for the decline of food prices using the method proposed by Toda and Yamamoto (1996) - Granger causality test. The authors concluded that agricultural prices are influenced by exchange rate and oil prices through various channels, which is confirmed by previous empirical studies of the Abbot et al. (2008).

Given the above, it should be noted that the history of the development of views on the question of relationship between agricultural prices, oil prices and exchange rate is quite long, and opinions are sometimes are diametrically opposed. With this in mind, the authors present a review of relevant literature in Table 1.

\section{Materials and methods}

\section{Research methods}

In this section, we provide an empirical strategy for achieving the above-mentioned goals of the study. In first place, we have to choose the best type of model for regression analysis -VECM model or unrestricted VAR model. For determining an appropriate type of the model, one should identify whether the variables used in the study are stationary at first difference and cointegrated.

In order to resolve the problem of non-stationarity of the data, all sampled time series are tested for the presence of unit root using traditional advanced Dickey-Fuller test (ADF test). The required number of lags is determined by information criteria of Akaike and Schwartzman:

$$
\Delta y_{t}=\delta+\beta_{t}+\pi y_{t-1}+\sum_{j=1}^{p} c_{j} \Delta y_{t-j}+\epsilon_{t}
$$

where $\delta$ - constant, $\mathrm{t}$ - trend value, $y_{t}$ - dependent variable (e.g., exchange rate), $\epsilon_{t}-$ white noise term; null hypothesis $\left(\mathrm{H}_{0}\right)$ is $\pi=0$ (presence of unit root), aleternative $\left(\mathrm{H}_{1}\right)-\pi<0$ (stationarity).

Secondly, if the condition of stationarity $\mathrm{I}(0)$ at first difference is obtained in all the variables used in this study, it is necessary to verify the presence of cointegrating equations in order to identify presence or absence of the relationship between each resulting and dependent variables in the long run.

To test for presence of cointegration we apply the Johansen test using non-stationary time series (values in levels). If between variables does exist a cointegration, the first-best solution would be using VECM model. An optimal number of lags according to Akaike information criterion for providing Johansen test is determined in VAR space. To conduct Johansen test, we estimate a VAR model of the following type:

\begin{tabular}{|c|c|c|c|}
\hline Author & Commodity & Method & Exchange rate - role \\
\hline $\begin{array}{l}\text { Johnson, Grennes } \\
\text { and Thursby (1977) }\end{array}$ & Wheat & $\begin{array}{l}\text { Deterministic short run forecasting } \\
\text { model }\end{array}$ & important \\
\hline Chambers and Just (1979) & General agriculture & Critique of exchange rate treatment & somewhat important \\
\hline $\begin{array}{l}\text { Collins, Meyers } \\
\text { and Bredahl (1980) }\end{array}$ & $\begin{array}{l}\text { Wheat, corn, soybeans } \\
\text { and cotton }\end{array}$ & Simple analytic method & overly restricted in models \\
\hline Chambers and Just (1989) & Wheat, corn, soybeans & Dynamic three stage least squares & important \\
\hline Chambers and Just (1981) & $\begin{array}{l}\text { Agricultural } \\
\text { vs non-agricultural sector }\end{array}$ & Vector auto-regression & important in the short run \\
\hline Bessler (1984) & Brazilian agricultural prices & Vector auto- regression & important \\
\hline $\begin{array}{l}\text { Batten and Belongia } \\
(1986)\end{array}$ & General agriculture & $\begin{array}{l}\text { Standard expression for export } \\
\text { determination }\end{array}$ & not important \\
\hline Orden and Fackler (1989) & General agriculture & $\begin{array}{l}\text { Non-recursive structurally identified } \\
\text { model }\end{array}$ & inconclusive \\
\hline $\begin{array}{l}\text { Robertson and Orden } \\
(1990)\end{array}$ & Agricultural prices & $\begin{array}{l}\text { Vector auto-regression and Vector } \\
\text { Error Correction }\end{array}$ & play a role \\
\hline $\begin{array}{l}\text { Henry, Peterson, Bessler } \\
\text { and Farris (1993) }\end{array}$ & Beef cattle & Time series based on Bayesian VAR & important \\
\hline $\begin{array}{l}\text { Babula,Ruppel and Bessler } \\
\text { (1995) }\end{array}$ & Corn & $\begin{array}{l}\text { Both structural econometric models } \\
\text { and time series methods }\end{array}$ & not important \\
\hline Vellianitis-Fidas (1976) & General agriculture & $\begin{array}{l}\text { Ordinary Least Squares and Time } \\
\text { Series }\end{array}$ & $\begin{array}{l}\text { not important in } \\
1972-1973\end{array}$ \\
\hline
\end{tabular}

Source: own elaboration

Table 1: Summary of relevant literature. 


$$
y_{t}=A_{1} y_{t-1}+\ldots+A_{p} y_{t-p}+B x_{t}+\epsilon_{t}
$$

in which each component of $y_{t}$ is non-reposeful series and it is integrated of order 1. $x_{t}$ is a fixed exogenous vector, indicating the constant term, trend term and other certain terms. et is a disturbance vector of $\mathrm{k}$ dimension.

We can rewrite this model as:

$$
\Delta y_{t}=\prod y_{t-1}+\sum_{i=1}^{p-1} V_{i} \Delta y_{t-1}+B x_{t}+\epsilon_{t}
$$

where:

$$
\prod=\sum_{i=1}^{p} A_{i}-I, \quad \bigvee_{i}=-\sum_{j=i+1}^{p} A_{j}
$$

if the coefficient matrix $\prod$ has reduced rank $r<k$, then there exist $k \times r$ matrices $\alpha$ and $\beta$ each with rank $r$ such that $\Pi=\alpha \beta^{\prime}$ and $\beta^{\prime} y_{t}$ is $\mathrm{I}(0)$. $r$ is the number of cointegrating relations (the cointegrating rank) and each column of $\beta$ is the cointegrating vector. The elements of $\alpha$ are known as the adjustment parameters in the VEC model. Johansen's method is to estimate $\prod$ matrix from an unrestricted VAR and to test whether we can reject the restrictions implied by the reduced rank of $\prod$.

In case of absence of cointegration between the sampled variables, a more appropriate method of regression analysis is the use of unrestricted VAR model:

$$
\begin{aligned}
Y i_{t}= & a_{0}+a_{1} Y_{t-1}+\ldots . .+a_{p} Y_{t-p}+b_{1} X_{t-1}+ \\
& \ldots . .+b_{p} X_{t-p}+u_{t}
\end{aligned}
$$

where $Y_{t}$ presents price value of agricultural commodity $i$ (resulting variable) at period t, $X_{t}$ presents price value of oil or value of national currency's exchange rate (explanatory variable).

Providing regression analysis of the sampled variables by modeling VAR allow us to determine the existence of substantial and statistically significant dependence not only on the values of other variables in the sample, but also dependence on previous values of the variable.

However, VAR model must meet the requirements of serial correlation's absence, homoscedasticity of the residuals and to meet the requirement of stability. Only in this case the results can be considered true.

The last stage to determine the relationship and its direction is the use of Granger causality test. So, rejection of the null hypothesis of Granger test
(H0), according to which:

$b_{1}=b_{2}=\ldots . .=b_{p}=0$,

in favor of the alternative hypothesis (H1) suggests that changes in oil prices or exchange rate of national currency granger cause changes in prices of agricultural commodities.

If unrestricted VAR model is appropriate for testing the variables of the study, one could also use impulse response analysis, providing information about sensitivity and elasticity of analyzed variables in the short-run.

\section{Materials and data processing}

The basis of statistical data for the study are monthly world oil prices, value of exchange rate of the Russian ruble/USD and monthly domestic prices of buckwheat, barley, potatoes, wheat, oats, rye and grain crops for the period from January 1999 to October 2015. The choice of this time span is due to the relative stability of agricultural prices during the 1990s. Since the end of 1990s, agricultural prices began to grow at a significant pace. In this study, we are interested in whether shocks in oil prices and dynamics of the exchange rate are able to explain the upward trend in agricultural prices.

Variable "oil prices" represents the average monthly spot prices for crude oil (Brent) in Europe. Data is obtained from the statistical database of the US Energy Information Administration (EIA). Variable "exchange rate" is the value of the Russian ruble to the US dollar at the beginning of each month. Data is obtained from the statistical database of the Bank of Russia. Data on monthly prices for agricultural goods is obtained from the database of the Federal Service of State Statistics of Russia (www.gks.ru).

To conduct time-series analysis, all variables were transformed into logarithms. To evaluate variables we use the method of descriptive statistics. To identify and formally assess the relationship between variables, we use simple correlation analysis. To study sensitivity of agricultural commodities' prices to shocks in oil prices and the exchange rate of the ruble in short-and long-run, we turn to regression analysis, which involves the construction of VAR model of certain type based on stationary time series, testing the model for heteroscedasticity of the residuals, autocorrelation as well as stability. Based on the model, we measure elasticity of variables in the short and long run by applying Granger causality test, as well as using impulse response analysis. 


\section{Results and discussion}

Descriptive statistics for variables are presented in Table 2. According to data of descriptive statistics, the exchange rate has the minimum values of the average, median, maximum, and standard deviation (0.1926). In the case of oil prices, the standard deviation from the trend (0.6136) represents the maximum value of the entire sample. Specific behavior of the exchange rate and low volatility relative to other variables is because that throughout the 2000s in Russia the exchange rate was under the control of monetary authorities and restrained within the legislative boundaries. In this regard, significant exchange rate fluctuations were excluded. The transition in recent years to the regime of free exchange rate undoubtedly has increased the volatility. In contrast, oil prices are characterized by the maximum value of the standard deviation, which suggests significant volatility. The same is true for the prices of agricultural goods. This feature is explained by the fact that oil prices are set on the world market and represent the ratio of supply and demand, as well as their dynamics.

$\mathrm{L}$ in each name of the variables denotes the logarithm (i.e. LB - logarithm of prices for barley; LBW - logarithm of prices for buckwheat; LCO - logarithm of prices for crude oil; LER - logarithm of exchange rate; LG - logarithm of prices for grain crops; LO - logarithm of prices for oat; LP - logarithm of prices for potatoes; LR - logarithm of prices for rye; LW - logarithm of prices for wheat).

If we turn to the results from simple correlation analysis (Table 3), we can detect a number of significant, at first glance, correlations. First, there is a significant linear relationship between the prices of various agricultural products.
For example, the correlation between barley and wheat tends to $1(0.981)$, and the correlation between barley and grain crops is 0.989 . Thus, a sudden shock in the price of one commodity can lead to changes in the price of other goods, traded on the market.

The results of correlation analysis also show the presence of a linear relationship between the prices of agricultural goods and oil prices. For example, it can be considered a strong correlation between oil prices and the prices of rye and oat ( 0.863 and 0.883 , respectively). However, this correlation may be misleading and the results cannot be considered fully reliable because of serial correlation issue.

The picture with the exchange rate looks not so clear. The degree of linear correlation between exchange rate and prices of agricultural products can be considered, at best, medium (0.3-0.5). This speaks in favor of the absence of a significant dependence of agricultural prices from exchange rate fluctuations. The reasons for this correlation may be the fact that Russia is a major international agricultural exporter. Therefore, shocks to exchange rate do not have a significant impact on domestic prices. However, it is important to remember that Russia is not a net exporter. The import channel affects a number of agricultural products included in the sample. In case of crop failure or inadequate supply the share of import of certain goods increases (for example, in the case of buckwheat).

Since the way of stochastic is different at each time point of the non-stationary series, general stochastic of the series is hard to capture. There is also the probability of obtaining spurious regression.

Thus, to resolve the problem with the nonstationarity of time series, it is necessary to test for the presence

\begin{tabular}{|l|c|c|c|c|c|c|c|c|c|}
\hline & LB & LBW & LCO & LER & LG & LO & LP & LR & LW \\
\hline Mean & 8.0819 & 8.7486 & 3.9815 & 3.4116 & 8.1997 & 7.9640 & 8.8345 & 7.9493 & 8.2168 \\
\hline Median & 8.0674 & 8.6807 & 4.0920 & 3.3783 & 8.2471 & 8.0287 & 8.8222 & 8.0392 & 8.2405 \\
\hline Maximum & 9.0092 & 10.641 & 4.8882 & 4.1986 & 9.2189 & 8.8643 & 9.9473 & 8.8422 & 9.1712 \\
\hline Minimum & 6.2429 & 7.1714 & 2.3292 & 3.1130 & 6.4164 & 6.4923 & 7.6680 & 6.1408 & 6.4149 \\
\hline Std. Dev. & 0.5746 & 0.5602 & 0.6163 & 0.1926 & 0.5580 & 0.5212 & 0.4639 & 0.5594 & 0.5489 \\
\hline Skewness & -0.4004 & 0.6585 & -0.4017 & 2.2891 & -0.3011 & -0.3813 & 0.3260 & -0.7634 & -0.2854 \\
\hline Kurtosis & 1.6513 & 2.2492 & 1.0860 & 2.3298 & 1.5584 & 1.3646 & 1.6622 & 1.1751 & 1.6676 \\
\hline Probability & 1632.5 & 1767.2 & 804.27 & 689.14 & 1656.3 & 1608.7 & 1784.5 & 1605.7 & 1659.8 \\
\hline Sum & 66.375 & 63.083 & 76.362 & 7.4592 & 62.604 & 54.606 & 43.264 & 62.912 & 60.574 \\
\hline Sum Sq. Dev. & 66.37523 & 63.08330 & 76.36233 & 7.459206 & 62.60486 & 54.60605 & 43.26464 & 62.91200 & 60.57406 \\
\hline Observations & 202 & 202 & 202 & 202 & 202 & 202 & 202 & 202 & 202 \\
\hline
\end{tabular}

Source: own processing 


\begin{tabular}{|c|c|c|c|c|c|c|c|c|c|}
\hline Variable & LB & LBW & LCO & LER & LG & LO & LP & LR & LW \\
\hline LB & 1.000 & & & & & & & & \\
\hline LBW & 0.775 & 1.000 & & & & & & & \\
\hline $\mathrm{LCO}$ & 0.866 & 0.667 & 1.000 & & & & & & \\
\hline LER & 0.423 & 0.479 & 0.122 & 1.000 & & & & & \\
\hline LG & 0.989 & 0.769 & 0.838 & 0.470 & 1.000 & & & & \\
\hline LO & 0.965 & 0.759 & 0.883 & 0.436 & 0.964 & 1.000 & & & \\
\hline LP & 0.840 & 0.795 & 0.756 & 0.502 & 0.832 & 0.865 & 1.000 & & \\
\hline LR & 0.961 & 0.708 & 0.863 & 0.339 & 0.956 & 0.954 & 0.789 & 1.000 & \\
\hline $\mathrm{LW}$ & 0.981 & 0.750 & 0.816 & 0.476 & 0.996 & 0.949 & 0.814 & 0.946 & 1.000 \\
\hline
\end{tabular}

Source: own processing

Table 3. Correlation matrix

\begin{tabular}{|l|l|l|l|l|}
\hline & \multicolumn{2}{|c|}{ ADF } & \multicolumn{2}{c|}{ PP } \\
\hline & \multicolumn{2}{|c|}{ Statistic Prob.** } & \multicolumn{2}{c|}{ Statistic Prob.** } \\
\hline Levels & & & & \\
\hline Intercept & 8.4421 & 0.9392 & 7.9174 & 0.9021 \\
\hline Intercept and trend & 7.3459 & 0.3187 & 5.4482 & 0.3685 \\
\hline & & & & \\
\hline First-difference & & & & \\
\hline Intercept & 770.82 & $0.0000^{* *}$ & 745.54 & $0.0000^{* *}$ \\
\hline Intercept and trend & 749.75 & $0.0000^{* *}$ & 720.58 & $0.0000^{* *}$ \\
\hline
\end{tabular}

Note: ** denotes statistical significance at the $5 \%$ level of significance Source: own processing

Table 4: Results of the group unit root test.

\begin{tabular}{|c|c|c|c|c|}
\hline Hypothesized No. of CE(s & Eigenvalue & Trace Statistics & 0.05 Critical Value & Prob.** \\
\hline None & 0.289 & 145.381 & 197.371 & 0.346 \\
\hline At most 1 & 0.236 & 127.868 & 159.530 & 0.203 \\
\hline At most 2 & 0.168 & 124.665 & 125.615 & 0.177 \\
\hline At most 3 & 0.153 & 88.343 & 95.754 & 0.145 \\
\hline At most 4 & 0.111 & 55.555 & 69.819 & 0.396 \\
\hline At most 5 & 0.085 & 32.328 & 47.856 & 0.594 \\
\hline At most 6 & 0.057 & 14.812 & 29.797 & 0.792 \\
\hline At most 7 & 0.014 & 3.109 & 15.495 & 0.962 \\
\hline At most 8 & 0.002 & 0.342 & 3.841 & 0.559 \\
\hline
\end{tabular}

Note: Trace statistics indicate no cointegrating equations at the 0.05 level.

* denotes statistical significance at the $5 \%$ level of significance

Source: own processing

Table 5: Results of Johansen co-integration test.

of unit root. The results of ADF and PhillipesPerron tests are presented in Table 4. The results show that the maximum order of integration is 1 $(d=1)$. This means that the first-differenced variables with constant and trend are stationary.

Once we have determined that all variables are stationary at first difference we can present Johansen cointegration test for determining the appropriate type of regression model to use in the study. For Johansen test we use non-stationary data to check for presence of relationship between sampled variables.

As can be seen from the results of the Johansen test (Table 5), cointegrating equations between variables have not been revealed. For all null hypotheses of no existence of cointegrating equations, values of trace statistics are less than critical values and $p$-values are more than 5 percent, and that allows us to accept the null hypothesis of no cointegration between variables. In other words, based on results 
of this test, using VECM model would be incorrect way of providing analysis, which leads us to the necessity of using an unrestricted VAR model.

Building a VAR model involves determining the optimal number of lags. In our case, the Akaike information criterion equals 2. Consequently, we built a model based on the use of time lag of 2 months to determine the relationship in the short term.

The model is used to determine the level of sensitivity of control variables (prices for agricultural goods) to shocks in oil prices and the exchange rate. For these goals, we apply pairwise Granger causality test and impulse response analysis.

The results of the diagnostic testing of the model for heteroscedasticity of residuals, autocorrelation, serial cross-correlation, and stability are presented in Figure 4 and Table 5. As can be seen from Table 5, the model is stable, heteroscedasticity and serial correlation of residuals in the model are absent. For testing sensitivity of agricultural prices to shocks in oil prices and exchange rate, we use impulse response function. Since the inverse roots are all depicted in the unit circle (Figure 4), we can say that the VAR model is stable and does not affect the standard deviation in impulse response function.

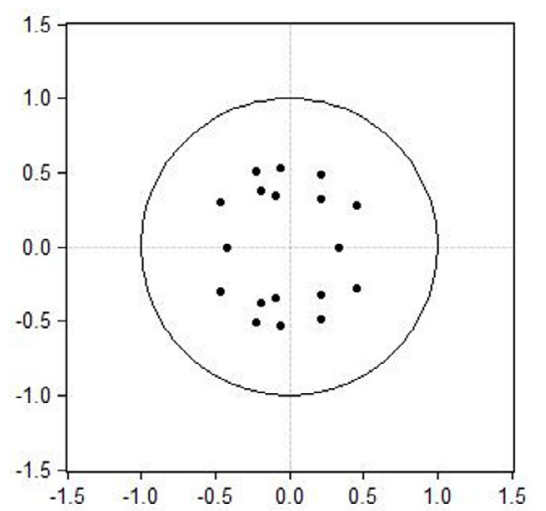

Source: own processing

Figure 4: Inverse roots of AR characteristic polynomial.

Granger causality test confirms the presence of a number of long-term relationships between the variables. Thus, in contrast to simple correlation analysis, Granger test (Table 7) shows the presence

\begin{tabular}{|c|c|c|c|}
\hline Type of test & \multicolumn{3}{|c|}{ Results } \\
\hline \multirow{2}{*}{$\begin{array}{c}\text { VAR Residual Serial } \\
\text { Correlation LM Test }\end{array}$} & Lags & LM-Stat & P-value \\
\cline { 2 - 4 } & 1 & 100.1202 & $0.0736^{* *}$ \\
\cline { 2 - 4 } & 2 & 92.8017 & $0.1743^{* *}$ \\
\hline Stability condition test & All roots lie within the circle. VAR satisfies stability condition. \\
\hline $\begin{array}{c}\text { Heteroscedasticity } \\
\text { (White test) }\end{array}$ & $0.1497^{*}$ \\
\hline $\begin{array}{c}\text { VAR Residual Cross } \\
\text { Correlation Test }\end{array}$ & \multicolumn{3}{|c|}{ No autocorrelation in the residuals } \\
\hline
\end{tabular}

Note: $* *$ denotes acceptance of null hypothesis (Ho: there is no serial correlation).

* denotes acceptance of null hypothesis of homoscedasticity.

Source: own processing

Table 6: Results of unrestricted VAR model diagnostic testing

\begin{tabular}{|c|c|c|c|c|c|c|c|c|c|}
\hline Variable & LB & LBW & LCO & LER & LG & $\mathrm{LO}$ & LP & LR & LW \\
\hline LB & & 0.221 & 0.305 & 1.868 & 0.576 & 2.127 & 0.336 & 0.586 & 0.991 \\
\hline LBW & 2.203 & & 3.959 & $10.879 *$ & 1.136 & 0.159 & 1.704 & 0.463 & 1.285 \\
\hline $\mathrm{LCO}$ & 1.066 & 0.626 & & 2.241 & 0.005 & 3.148 & 2.618 & 2.534 & 0.626 \\
\hline LER & 5.279 & 2.669 & 4.318 & & 2.369 & 1.070 & 1.398 & 0.575 & 4.672 \\
\hline LG & $11.718^{*}$ & 0.340 & 0.985 & 3.822 & & 0.087 & 0.447 & 1.627 & $6.809 *$ \\
\hline LO & $16.743 *$ & 0.267 & 3.190 & 0.433 & 0.909 & & $5.978 *$ & $11.380 *$ & 0.749 \\
\hline LP & 4.108 & 1.633 & 0.021 & 0.581 & 2.117 & 1.307 & & 1.660 & 1.363 \\
\hline LR & $9.509 *$ & 1.190 & 3.127 & 0.232 & 2.565 & 0.535 & 0.496 & & $5.847^{*}$ \\
\hline LW & $9.438 *$ & 0.639 & 0.545 & 1.550 & 0.384 & 0.365 & 0.450 & 3.447 & \\
\hline
\end{tabular}

Note: * denotes statistical significance at the $5 \%$ level of significance and rejection of null hypothesis of no Granger causality.

Source: own processing 
of a long-term relationship between the exchange rate and the prices of buckwheat. At the same time, the Granger causality between exchange rate and other agricultural commodities is missing. This result is explained by the fact that for most of agricultural products, Russia is a net exporter and the channel of exchange rate has no significant impact on prices in the agro-industry. In the case of buckwheat, Russia is both a producer and importer. In case of droughts, crop failures, artificial panics in the agricultural market ("Buckwheat mania" of 2010-2011, crop failure of 2013), as well as increasing production costs and restriction of free pricing, lead to a loss of competitiveness of domestic producers. In 2014-2015, significant role in increasing domestic prices has played a sharp and strong depreciation of the ruble.

The absence of Granger causality from oil prices to agricultural commodities is also due to the exporting status of Russia. No need for import of crude oil reduces sensitivity of domestic agricultural price fluctuations to the world market.

Thus, in the group of agricultural commodities, on which Russia is a net exporter, sensitivity to shocks in oil prices and exchange rate tends to zero. For those agricultural goods that are imported (e.g. buckwheat), the channel of the exchange rate manifests itself in the long run.

To assess the link between agricultural prices and oil prices and exchange rate in the short term, we turn to impulse response analysis. This technique allows us to assess sensitivity of control variables to shocks in oil prices and exchange rate in the short run on the basis of the constructed VAR model. The results of impulse response analysis are presented in Figures 5-6.

The results of impulse-response analysis confirm the overall results of the Granger test. In the short term and in the long-term sensitivity of buckwheat prices to shocks in the exchange rate is manifested. In other cases, statistically significant elasticity could not be detected. Thus, the results of impulse response function show a statistically significant sensitivity of prices for buckwheat to changes in the exchange rate of the national currency of Russia in the short term. Judging by the results, the shock (in one standard deviation) on the currency market leads to an increase
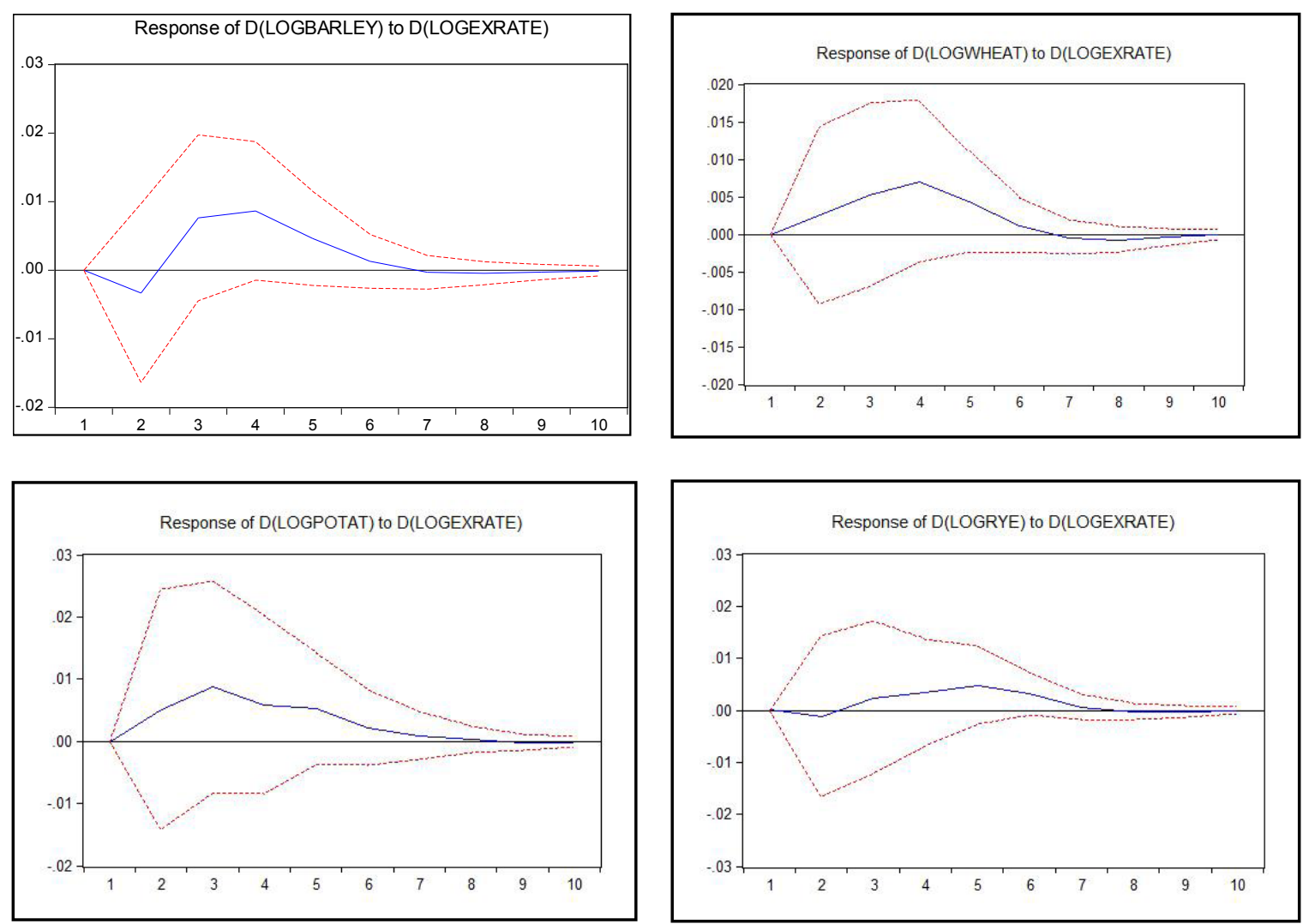

Source: own processing

Figure 5: Response to one-standard deviation of the exchange rate. 

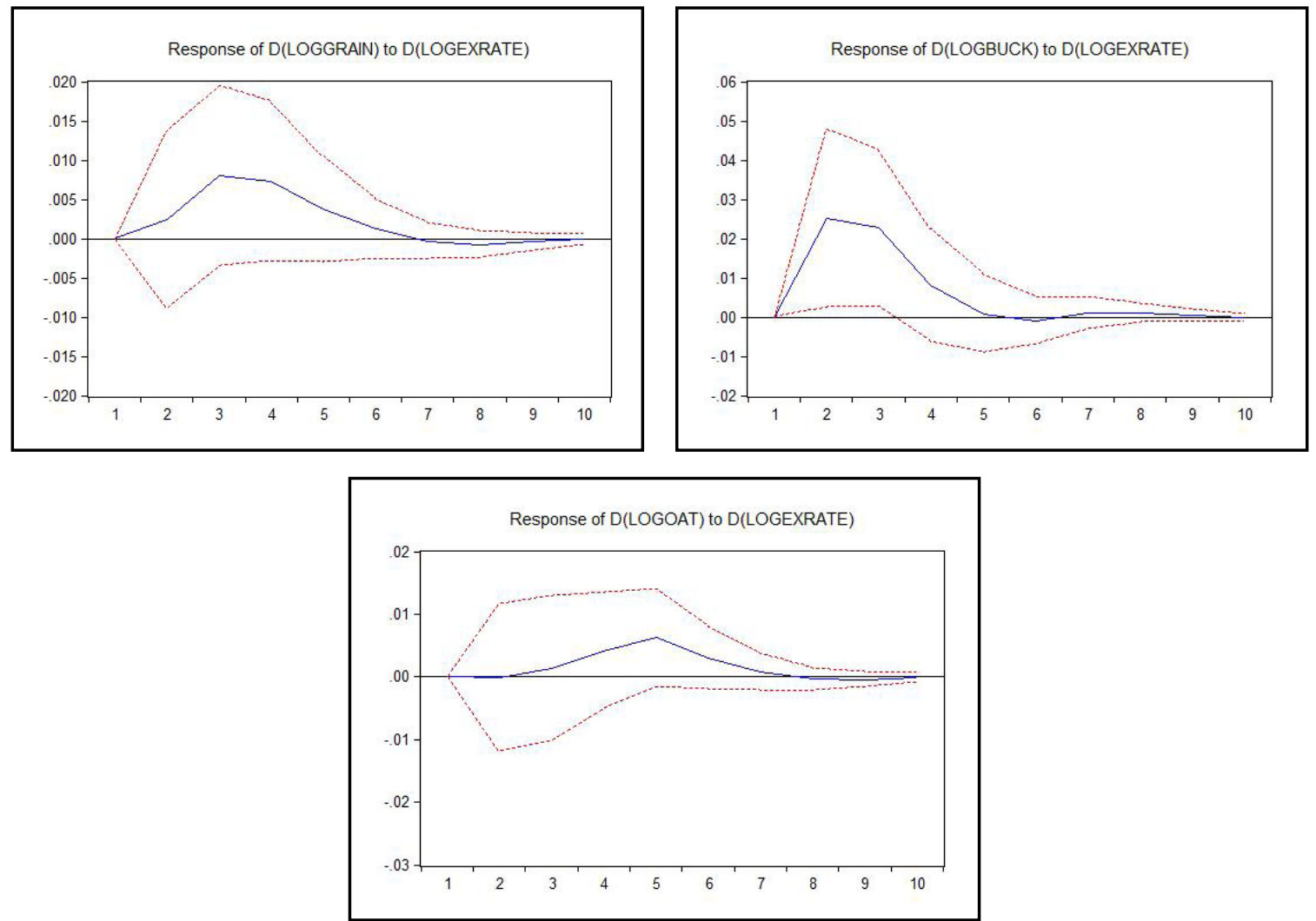

Source: own processing

Figure 5: Response to one-standard deviation of the exchange rate. (continuation)
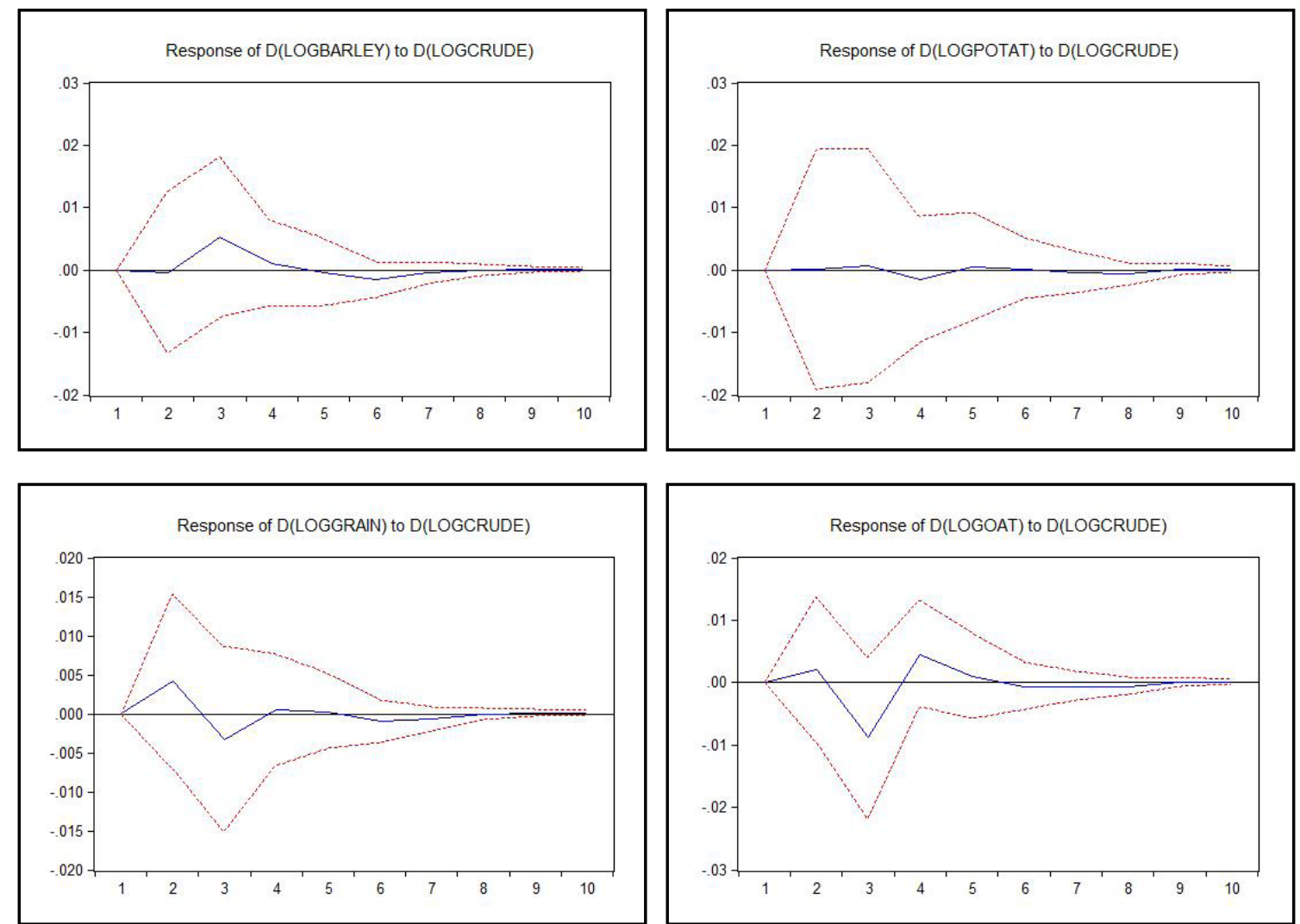

Source: own processing

Figure 6: Response to one-standard deviation of world oil price. 

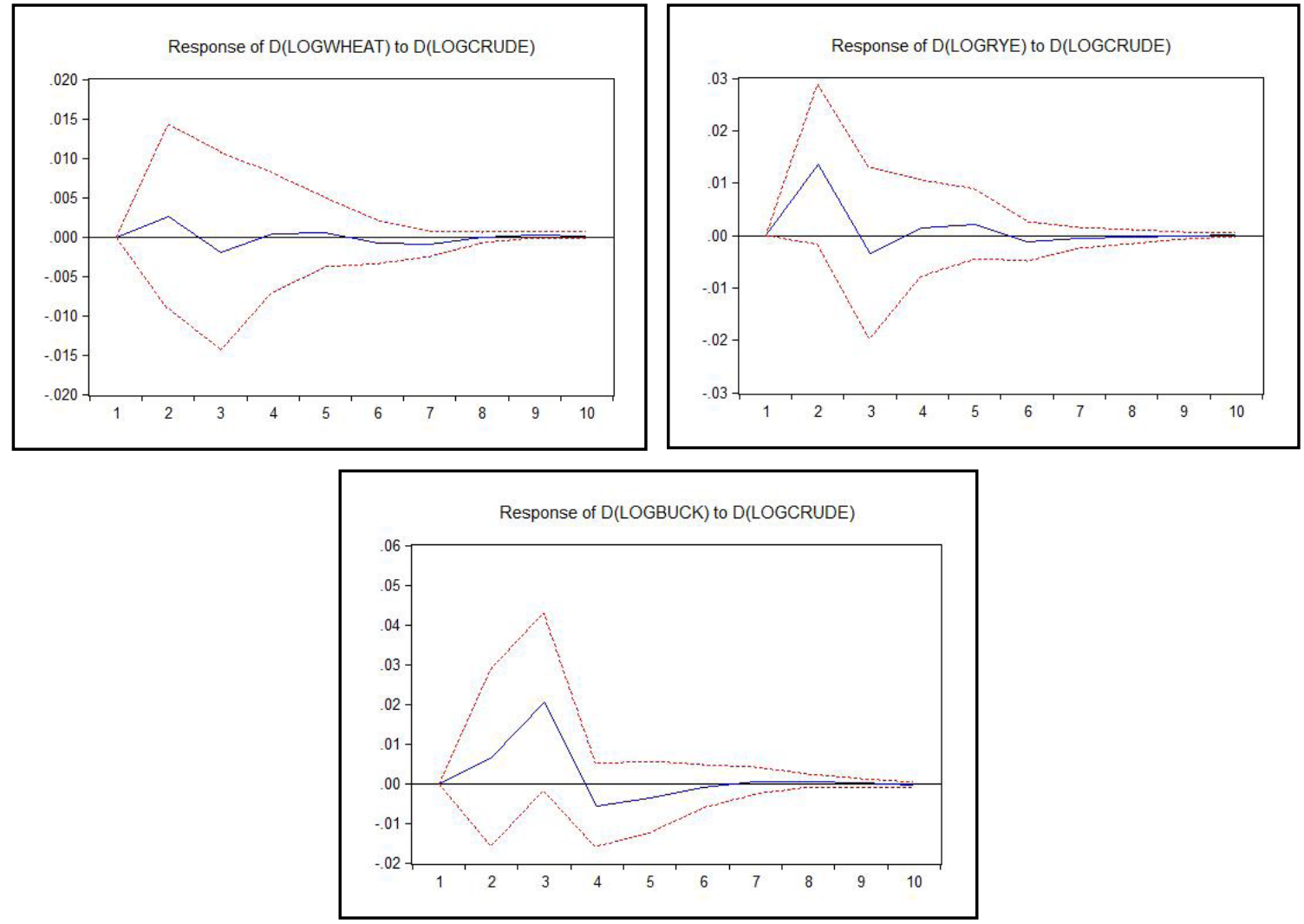

Source: own processing

Figure 6: Response to one-standard deviation of world oil price (continuation).

in output prices for buckwheat on the domestic market within a maximum of three months from the moment of shock occurrence. This result suggests the necessity of taking into account the relationships between production, planning, selling prices, as well as developing mechanisms of currency risk hedging in the agricultural industry. In addition, recognizing sensitivity in the prices of buckwheat to shocks on the foreign exchange market speaks in favor of increasing domestic production and enhancing national food security as well as developing mechanisms mitigating realization of currency risk in relations with trade partners. The lack of sensitivity of agricultural prices to changes in oil prices are explained by the exporting status of Russia. The availability of domestic energy resources allows to protect domestic agricultural prices from fluctuations in the world oil market.

\section{Conclusion}

This study focuses on the analysis of relationships and determining sensitivity of agricultural prices to oil prices and exchange rate. The definition of the character of interrelations in the national economy is important to ensure macro-economic wellbeing and food security. A clear understanding of the links between agricultural prices, oil prices and the exchange rate is a key prerequisite for the formation of optimal monetary and fiscal policy. Analyzing sensitivity of Russian agricultural market to shocks in world oil prices and exchange rate, we come to conclusion that the status of an exporter of agricultural products significantly protects the national economy from the effects of adverse shocks.

However, at the same time, changes in oil prices and exchange rate are not sufficient to explain an increase in domestic agricultural prices, which could be the subject of further research.

In the case of importer's status (for Russia - import of buckwheat), sensitivity to exogenous shocks of exchange rate (under condition of free market pricing) increases dramatically, which creates a threat to food security and welfare of the population. Thus, an additional argument is given to the position according to which the transmission channel of exchange rate plays a significant role in pricing mechanism of agricultural products.

At the same time, there are a number of other channels that have potential to impact domestic 
prices for agricultural products. One of the key in our opinion may be growing demand for fertilizers and technologies for agricultural sector.
Transmission of currency risk in domestic agricultural market may be found through increasing demand in raw materials.

Corresponding author:

Dr. Dmitry Burakov

Department of Monetary Relations \& Monetary Policy

Financial University under the Government of Russian Federation

Leningradsky prospect, 49, 125993, Moscow, Russia

E-mail:dbur89@yandex.ru

\section{References}

[1] Abbott, P. C., Hurt, C. and Tyner W. E. (2008) „What's Driving Food Prices?“, Farm Foundation Issue Reports, July 2008.

[2] Babula, R. A., Ruppel, F. J. and Bessler, D. A. (1995) „U.S. corn exports: the role of the exchange rate“, Agricultural Economics. Vol. 13, pp. 75-88.

[3] Baffes, J. (2007). „Oil spills on other commodities“, World Bank Policy Research Working Paper No. 4333, World bank. [Online] Available: http://ssrn.com/abstract=1010818 [Accessed Sept. 6, 2015].

[4] Batten, D. S. and Belongia M. (1984) „The recent decline in agricultural exports: is the exchange rate the culprit?" Federal Reserve Bank of St. Louis Review. Vol. 66, pp. 5-14. ISSN 0014-9187.

[5] Batten, D. S. and Belongia, M. T. (1986) „Monetary policy, real exchange rates, and U.S. agricultural exports“, American Journal of Agricultural Economics, 68: 422-427. ISSN 1467-8276.

[6] Bessler, D.A. (1984), Relative prices and money: a vector autoregression on Brazilian data“, American Journal of Agricultural Economics. Vol. 66, pp. 25-30. ISSN 1467-8276. DOI: 10.2307/1240612.

[7] Campiche, J. L., Bryant, H. L., Richardson, J. W. and Outlaw, J. L. (2007) „Examining the Evolving Correspondence Between Petroleum Prices and Agricultural Commodity Prices“, In: Proceeding of the AAEA Meeting, Portland, OR, July 29-August 1.

[8] Chambers, R. G. (1984) „Agricultural and financial market interdependence in the short run“, American Journal of Agricultural Economics. Vol. 66, pp. 12-24. ISSN 1467-8276. DOI: $10.2307 / 1240611$.

[9] Chambers, R.G., Just R.E. (1979) „A critique of exchange rate treatment in agricultural trade models“, American Journal of Agricultural Economics. Vol. 61, pp. 249-257. ISSN 1467-8276. DOI: $10.2307 / 1239729$.

[10] Chambers, R. G. and Just R. E. (1981) „Effects of exchange rate changes on U.S. agriculture: a dynamic analysis“, American Journal of Agricultural Economics, 63: 32-46. ISSN 1467-8276. DOI: $10.2307 / 1239809$.

[11] Chambers, R.G., Just R.E. (1989) „Estimating multioutput technologies“, American Journal of Agricultural Economics. Vol. 71, pp. 980-995. ISSN 1467-8276. DOI: 10.2307/1242674.

[12] Collins, K. J., Meyers, W. H. and Bredahl, M. E. (1980) „Multiple exchange rate changes and U.S. agricultural commodity prices“, American Journal of Agricultural Economics. Vol. 62, pp. 656-665. ISSN 1467-8276.

[13] Du, X., Hayes, D. J. and Yu, C. (2011) „Dynamics of biofuel stock prices: A Bayesian approach“, American Journal of Agricultural Economics. Vol. 93, pp. 418-425. ISSN 1467-8276.

[14] Engle, R. F., Granger, C. W. J. (1987) „Co-integration and Error correction: representation, estimation, and testing“, Econometrica. Vol. 55, pp. 251-276. ISSN 1468-0262. DOI: 10.2307/1913236. 
[15] Esmaeili, A. and Shokoohi, Z. (2011) „Assessing the effect of oil price on world food prices: Application of principal component analysis“, Energy Policy. Vol. 39, pp. 1022-1025. ISSN 0301-4215. DOI: 10.1016/j.enpol.2010.11.004.

[16] FAOSTAT (2015) Food and Agriculture Organization of the United Nations [DB/OL]. [Online] Available at www.faostat.org [Accessed August 20, 2015].

[17] Hanson, K., Robinson, S. and Schluter, G. (1993) „Sectoral effects of a world oil price shock: economy wide linkages to the agricultural sector", Journal of Agricultural and Resource Economics. Vol. 18, pp. 96-115. ISSN 1467-8489.

[18] Harri, A., Nalley, L. L. and Hudson, D. (2009) „The relationship between oil, exchange rates, and commodity prices“, Journal of Agricultural and Applied Economics. Vol. 41, pp. 501-510. ISSN 1074-0708.

[19] Henry, G., Peterson, E. W. F., Bessler, D. and Farris, D. (1993) „A time-series analysis of the effects of government policies on the U.S. beef cattle industry“, Journal of Policy Modeling. Vol. 15, pp. 117-139. ISSN 0161-8938.

[20] Johansen, S. (1988) „Statistical analysis of co-integration vectors“, Journal of Economic Dynamics and Control. Vol. 12, pp. 231-254. ISSN 0165-1889.

[21] Johnson, P. R., Grennes T., Thursby M. (1977) „Devaluation, foreign trade controls, and domestic wheat prices“, American Journal of Agricultural Economics. Vol. 59, pp. 619-627. ISSN 1467-8276.

[22] Keith, C. (2008) „The role of Recent Developments with a Focus on Feed Grain Markets and Market Prospects: A Review of Recent Development with a Focus on Feed Grain Markets and Market Prospects“, Supporting material for a review conducted by Kraft Foods Global, Inc. of the current situation in farm and food markets, June 19, 2008.

[23] Kost, W. E. (1976) „Effects of an exchange rate change on agricultural trade“, Agricultural Economics Research. Vol. 28, pp. 99-106. ISSN 0303-1853, E-ISSN 2078-0400.

[24] Kwon D., Koo W. W. (2009) „Price transmission channels of energy and exchange rate on food sector: A disaggregated approach based on stage of process“. In: Agricultural \& Applied Economics Association 2009 AAEA \& ACCI Joint Annual Meeting, Milwaukee, Wisconsin, July 26-29, 2009.

[25] Nazlioglu, S.(2011),,World oil and agricultural commodity prices: Evidence from nonlinearcausality“, Energy Policy. Vol. 39, pp. 29352943. ISSN 0301-4215. DOI: 10.1016/j.enpol.2011.03.001.

[26] Orden, D. and Fackler, P. L. (1989) „Identifying monetary impacts on agricultural prices in VAR models“, American Journal of Agricultural Economics. Vol. 71, : 495-502. ISSN 1467-8276. DOI: $10.2307 / 1241620$.

[27] Roache, S. K. (2012) „China’s Impact on World Commodity Markets“, IMF Working Paper WP/12/115, International Monetary Fund.

[28] Robertson, J. C. and Orden, D. (1990) „Monetary impacts on prices in the short and long run: some evidence from New Zealand“, American Journal of Agricultural Economics. Vol. 72, pp. 160-171. ISSN 1467-8276. DOI: $10.2307 / 1243156$.

[29] Schuh, G. E. (1974) „The exchange rate and U.S. agriculture“, American Journal of Agricultural Economics. Vol. 57, pp. 1-13. ISSN 1467-8276. DOI: 10.2307/1239342.

[30] Toda, H. Y., Yamamoto, T. (1995) „Statistical inference in vector autoregressions with possibly integrated processes“, Journal of Econometrics. Vol. 166, p. 225-250. ISSN 0304-4076. DOI: 10.1016/0304-4076(94)01616-8.

[31] U.S. (2015) Department of Energy [DB/OL]. [Online] Available at http:// www.energy.gov/ energysources/bioenergy.htm [Accessed Sept. 15, 2015].

[32] Vellianitis-Fidas, A. (1976) „The impact of devaluation on U.S. agricultural exports“, Agricultural Economics Research. Vol. 28, pp. 107116.SSN 0303-1853, E-ISSN 2078-0400. 
[33] Von Braun, J. (2008) „Rising food prices: what should be done?“, Eurochoices. Vol. 7, pp. 30-35. ISSN 1746-692X. DOI: 10.1111/j.1746-692X.2008.00099.x.

[34] Wang, Y., Wu C. and Yang, L. (2014) „Oil price shocks and agricultural commodity prices“, Energy Economics. Vol. 44, pp. 22-35. ISSN 0140-9883. DOI: 10.1016/j.eneco.2014.03.016.

[35] Yu, T., Bessler, D. A. and Fuller, S. W. (2006) „Cointegration and Causality Analysis of World Vegetable Oil and Crude Oil Prices“, In: American Agricultural Economics Association 2006, Annual meeting, July 23-26, Long Beach, CA

[36] Zhang, Q. and Reed, M. R. (2008) ,Examining the Impact of the World Crude Oil Price on China's Agricultural Commodity Prices: The Case of Corn, Soybean, and Pork“, In: 2008 Annual Meeting, Feb 2-6, 2008, Dallas, Texas. 